2. Клименко Н.Ф., Карпіловська Є.А., Кислюк Л.П. Динамічні процеси в лексиконі сучасної української мови : монографія. - К. : Видавничий дім С. Бураго, 2008. 335 с.

DOI https://doi.org/10.30525/978-9934-26-039-1-2

\title{
НАЙМЕНУВАННЯ ОСІБ ЗА СПОРІДНЕНІСТЮ В СТАРОУКРАЇНСЬКІЙ АКТОВІЙ МОВІ XV - XVI СТ.
}

\author{
Дяченко Г. Г. \\ магістрантка \\ Навчально-наукового інституту украӥнської філології \\ та соиіальних комунікаиій \\ Черкаського національного університету імені Богдана Хмельницького \\ м. Черкаси, Україна
}

Вивчення писемних пам'яток надасть нам інформацію про державнотериторіальний устрій України в XV - XVI ст., про соціальну структуру суспільства зазначеного періоду, а також дослідження історичних документів ділового стилю дасть змогу з'ясувати роль і функції староукраїнської мови для розвитку сучасної української мови, зокрема iї ділового стилю [5]. У нашому дослідженні ми розглянемо найменування осіб за спорідненістю в актовій мові XV - XVI ст., що кваліфікуються за родовим поняттям, охоплюють назви осіб за спорідненістю такі лексеми: сім'я, родина, рід. Слово родина називає «групу людей, що складається з чоловіка, дружини, дітей та інших близьких родичів, які живуть разом; сім'я» [1, с. 1038]. Особу, яка перебуває з ким-небудь у кровній спорідненості, походить від спільних предків, називають родичем [1, с. 1038].

Серед назв осіб за родинною спорідненістю в актовій мові трапляються такі лексеми: чоловік, жонъка, жона, дружина, матка, батько, сестра та ін.

Лексема чоловік уживається лише в передмові до грамот на позначення одруженої особи стосовно своєї дружини, однак у самому тексті грамот ужито лексему мужъ: я, хвєдка Пашкова...даровала єсми своєю дю(б)рою волєю мужа своє(г) пана Васи(л)я Хрє(б)товича $[3$, c. 49$]$. 
У заповітних грамотах зафіксовано такі лексеми: дружина, син та родичі, яким київський намісник Роман-Олізар Волчкевич заповідає своє рухоме і нерухоме майно [3, с. 26]. Згадано в документах і Марину, дружину воєводи Олександра, названу в грамоті госпожою [3, с. 84], яка разом з чоловіком дарують монастиреві в Нямці болото на Дністрі, що зветься Загорноє, пасіку і щорічно по 12 бочок вина за своєю доброю волею для того, щоб надати допомогу монастирю. У монастирі мали правити літургію щонеділі за їхнє здоров'я і за пам'ять спочилих батьків. Марина названа в документах благочестивою госпожою [3, с. 84]. Найбільшим підтвердженням слів воєводи була їхня віра, віра їхніх дітей та інших людей, що служили при дворі та які названі в документальних актах. Згадано в грамотах дружину Михула Андроника пані Марту [3, с. 114]. Синонімічною до лексеми дружина є жона, жонъка. Остання лексема може позначати родинні стосунки заміжня особа стосовно до свого чоловіка [1, с. 277].

На позначення дітей ужито такі лексеми: дђти, сынъ, до(ч)ка, чада.

Лексема дђти уживається як на позначення синів або дочок своїх батьків [1, с. 288]: даль тую трєтину зємли церковную вђшно и нєпорухомо и напєрєдъ будучими Архимандриты нєрухомо и дђтємь нашимъ и правнучатомъ нашимъ [3, с. 31], так і на позначення усього народу (таке значення словниками не засвідчене).

Особу чоловічої статі стосовно своїх батьків називають сином. Лексему синъ згадано на початку грамоти в їі вступній частині, при цьому названо ім'я та прізвище сина: я пани Настасья пана Родивона Чижєвая исъ своимъ сином. паномъ Сємєномъ Чижєвичємь били єсмо чєломъ [3, с. 30]. У сучасних лексикографічних працях зафіксовано сім значень лексеми син, проте в актовій діловій мові вона вживається лише на позначення «особи чоловічої статі стосовно своїх батьків» [1, с. 1122]. Згадано в діловій актовій мові і сына государева Романа [3, с. 92]. Лексема $\partial о($ ч)ка на позначення «особи жіночої статі стосовно своїх батьків» [1, с. 245] уживається в грамоті про пані Хведку Пашкову, яка $\epsilon$ дочкою Духновича.

Уживаною в актовій мові є лексема чада, що має форми множини та позначає переважно дітей; однак словник фіксує цю лексему як жартівливе, проте варто не погодитися 3 цією стилістичною ремаркою, адже ділова мова не містить стилістичного забарвлення, тому можна робити висновок лише про архаїзацію лексеми, а не іiі стилістичний відтінок. Це слово має ще кілька сем, зокрема підданий, той, хто підлягає старшому (цареві, королю) [1, с. 1369]. 
На позначення дітей сина чи дочки ужито лексему онуки та зменшувально-пестливу лексему внучатко [1, с. 152], що в староукраїнській мові має теж пестливе забарвлення: оунучата [3, с. 94] - внуча: даруючи одному із своїх підданих два села за вірну службу, воєвода Ілля зазначає, що дає села на вђки. занужє дали єсми жбу... єго и братїамъ єго и оунучатю(м) єго. и пр[аоу]нучато(м) єго [3, с. 94], де вжито лексему правнуча - син або дочка внука чи внучки [1, с. 917], також ужито й лексему правнучата [3, с. 31].

На позначення одного з батьків ужито лексему родитєль. Це слово функціонує в грамотах із означенням почивщій, тобто згадують померлих батьків у випадках, коли дарують на милість монастиря якусь нерухомість за те, щоб за батьками правилась божественна літургія. Так титуловані особи, вірячи в Бога, своїми діями і власним прикладом підтверджували свою віру.

Лексема родитєль уживається й на позначення лише батька. Так, воєвода Петро підтверджує право Німецького монастиря на володіння озером Загорним, дане його батьком воєводою Олександром: дали єсми, и потвръдили, данна родитєлђ нашого стого почившаго АлекZандра воєводи [3, с. 105]. На позначення матері в актовій мові функціонують лексеми: матєръ і матка. У передмові до однієї з грамот, де йдеться про повернення слузі Швидригайла Ольгердовича Сенькові Хом'яку спадковий маєток його батька, ужито лексему батько, хоч у самій грамоті замість цісї лексеми ужито ючыноу [3, с. 38]. Синонімічна в сучасній мові лексема отецьь має відтінок урочистості й уживається на позначення вищого духовенства: $\omega($ m)ецъ митрополить, $\omega($ m)ецъ наш король [3, с. 63].

Старшим родичем по висхідній лінії 3 боку матері чи батька (звичайно старіший за діда, бабу) є предок 'той, від кого веде початок рід’ [1, с. 920]. У документах згадано предків воєводи Петра, який підтверджує привілеї, дані його предками Молдовицькому монастиреві на право володіння циганськими сім'ями: принєсли привилїє наши $(x)$ прє(д)ко(в) прђ(д) нами на потвєрждєнїє що дали наши родитєле [3, с. 103]. Синонімічною до лексеми прє(д)ки є лексема прєдии: $u$ стороны свои наити ка(к) и наши прє(д)чи имђл(и) [3, с. 106] та прамурать [3, с. 83].

На позначення кровної спорідненості по другій лінії ужито лексему дядко - 'брат матері або батька': панъ ивашко дядко дђтєи кнзя юрьєвыхъ [3, с. 40]. Дядька по материній лінії називають вуйком, який в 
сучасній мові є діалектизмом: принєсли привилїє вєликоє. Що имаю(m) $\omega(m)$ оуика нашого покоиника Стефана воєводи [3, с. 110].

На позначення сина стосовно до інших дітей одних батьків уживається лексема братъ. У грамотах трапляється сполучення апелятива 3 антропонімом на позначення брата князя Юрія Михайловича - Андрія [3, с. 32]. Панъ Шєфул Жумъ татєвичъ мав брата пана мьгндру [3, с. 92].

В актовій мові лексему братаничь ужито 3 антропонімом на позначення імені та прізвища та 3 апелятивом панъ юлє $(x)$ но чжус [3, с. 67] та має значення 'двоюрідний брат'.

Лексему сестра ужсто на позначення дочки стосовно до інших дітей того самого батька чи матері. Пахарнічела Сіма мав сестру Аннушку $[3$, c. 130]. В одній із грамот серед родичів Івана Шушмана згадано сестер на ім'я Магда і Мара [3, с. 127].

Отже, лексика на позначення родинних стосунків активно функціонує в діловій мові XV - XVI ст. На позначення осіб чоловічої статі функціонують такі лексеми: мужъ, синъ, родитєлъ, оунукъ, плєминникъ, предок, братъ, дядко, оуикою Лексема ютець на позначення родинних стосунків у староукраїнській мові не вживалася, лише на позначення титулованих осіб та духовенства.

На позначення осіб жіночої статі уживаються такі лексеми: жона, матєръ, сєстра, дочька. Більшість апелятивів уживаються 3 антропонімними компонентами на позначення імені чи прізвища особи.

Лексеми дid, баба в діловій мові не зафіксовані. На позначення зачинателів роду ужито лексеми прєдокъ, прєдии, пращуръ; молоде покоління названо дђти, чадо, нащадок. Назви осіб, які трапляються в документах, $\epsilon$ або спадкодавцями, дарувальниками або спадкоємцями відповідного майна.

Отже, актова ділова мова має розгалужену систему документів: акти, протоколи, грамоти, офіційні листи очільників держав, судові документи (рішення, судові вироки), метрики, промови керівників держав, угоди між державами та окремими власниками маєтків, монастирів, сіл, іншого нерухомого майна. Загальна кількість дібраних із грамот лексем 128 одиниць. Зокрема, ЛСГ «Найменування осіб за спорідненістю» охоплює 26 назв, що дорівнює 20, 3\%. Широко функціонують в досліджуваному джерелі назви осіб за спорідненістю та свояцтвом, що не залежить від станової належності осіб, що й слугуватимуть подальшим дослідженням наукових студій. 


\title{
Література:
}

1. Великий тлумачний словник сучасної української мови (з дод. i допов.). [уклад. і голов. ред. В. Т. Бусел]. Київ; Ірпінь : ВТФ «Перун», 2005. $1728 \mathrm{c}$.

2. Пещак М. М. Типи українських грамот XIV ст. та їх стилістичні особливості. Мовознавство. 1970. № 6. С. 58-65.

3. Українські грамоти XV ст. Підготовка тексту, вступна стаття і коментарі В. М. Русанівського. Київ : Наукова думка, 1965. 163 с.

4. Сухомлин I. Д. Питання становлення структури особових власних назв на основі народної антропонімічної системи української мови (За матеріалами пам'яток XIV-XVII ст. Українська лексика. Відп. ред. В. С. Ващенко. Дніпропетровськ : ДДУ, 1973. С. 3-19.

5. Худаш М. Л. Лексика українських ділових документів кінця XVI-початку XVII ст. (на матеріалі Львівського Ставропігіївського братства). Київ : Вид-во АН УРСР, 1961. 164 с.

DOI https://doi.org/10.30525/978-9934-26-039-1-3

\section{СЕМАНТИЧНА СТРУКТУРА ПРИКМЕТНИКІВ НА ПОЗНАЧЕННЯ ВЕЛИКОГО / МАЛОГО ЗАГАЛЬНОГО РОЗМІРУ (НА ПРИКЛАДІ ДРАМАТИЧНИХ ТВОРІВ ЛЕСІ УКРАЇНКИ)}

\author{
Клак О. С. \\ кандидат філологічних наук, \\ доцент кафедри іноземних мов та культури фахового мовлення \\ Львівського державного університету внутрішніх справ \\ м. Львів, Украӥна
}

Прикметники на позначення розміру (параметричні прикметники) об'єднують у єдину лексико-семантичну групу на основі інтегрального компонента «розмір фізичних об'єктів». Ця мікросистема неодноразово була об'єктом аналізу в науковій літературі на матеріалі різних мов (Н. Береговенко, Н. Векуа, А. Висоцький, Н. Дідух, А. Журинський, T. Линник, М. Петришин, Г. Шипіцина тощо), проте актуальним $є$ дослідження функціювання іï конституентів у художньому тексті, де вони часто виходять за межі своєї лексико-семантичної групи.

Лексична структура параметричних прикметників у драматичних творах Лесі Українки представлена одиницями, які формують окремі 